\title{
HISTOPATHOLOGICAL CHANGES OF THE KIDNEYS AND LIVER IN ALLOXAN-INDUCED DIABETIC MICE TREATED WITH GOUTWEED (AEGOPODIUM PODAGRARIA L.) MEDICINES
}

\author{
O.V.Tovchiga, V.O.Synytsia*, S.Yu.Shtrygol', N.V.Besditko
}

\author{
National University of Pharmacy \\ Chernigiv Regional Pathoanatomical Bureau*
}

Key words: mice; alloxan-induced diabetes; kidney; liver; goutweed

\begin{abstract}
The influence of the goutweed dry extract $(1 \mathrm{~g} / \mathrm{kg}$ ), goutweed tincture (1 and $5 \mathrm{ml} / \mathrm{kg}$ ) and "Arphasetin" tea infusion $(18 \mathrm{ml} / \mathrm{kg})$ on the histological structure of the kidneys and liver in alloxan-induced diabetic mice has been investigated. In three weeks after the pathological process induction in the nontreated mice dystrophic changes with the partial transition to necrobiosis and necrosis in the kidneys and liver, protein casts within the renal tubuli and lympholeucocytal infiltration in the liver were found. The goutweed dry extract $(1 \mathrm{~g} / \mathrm{kg})$ and "Arphasetin" tea infusion $(18 \mathrm{ml} / \mathrm{kg})$ normalize the structure of the renal tubuli (granular dystrophy of the kidney epithelium and necrobiosis foci in some histological samples were evident), prevent pathological changes of hepatocytes (on the background of the extract the vascular plethora, hepatocytes granular dystrophy and hypertrophy of some cells were detected, on the background of "Arphasetin", in addition to the abovementioned changes, single necrobiosis foci were registered). Necrobiosis and necrosis were not detected in the kidneys and liver of the animals treated with the goutweed tincture in the of dose of $5 \mathrm{ml} / \mathrm{kg}$, but the vascular plethora was present. Granular dystrophy of the epithelium and protein casts within some tubuli were seen in the kidneys, granular dystrophy of hepatocytes was registered in the liver. The goutweed tincture in the dose of $1 \mathrm{ml} / \mathrm{kg}$ did not show the protective action on the histological structure of the kidneys and liver. Thus, a dry extract of goutweed $(1 \mathrm{~g} / \mathrm{kg})$, the goutweed tincture (5 ml/kg, but not $1 \mathrm{ml} / \mathrm{kg}$ ) and "Arphasetin" tea infusion (18 ml/kg) improve the histological structure of the kidneys and liver in alloxan-induced diabetic mice, prevent necrosis development and infiltration of tubuli with protein casts. The goutweed extract in the dose of $1 \mathrm{~g} / \mathrm{kg}$ is considered to be the most promising medicine for further research.
\end{abstract}

The prevalence of diabetes mellitus (DM) is constantly increasing, it contributes essentially to the general structure of mortality, impaires the quality of life and ability to work. So, the problem of improving DM treatment remains essential [13]. Being one of the most dangerous complications of diabetes, nephropathy develops in $20-40 \%$ of patients and progresses to irreversible decline in the renal function with the need in substitution therapy [8]. Furthermore, even in the absence of obesity in $24 \%$ of patients with type I diabetes and in $80 \%$ of patients with type II diabetes the nonalcoholic fatty liver disease is registered [10]. Therefore, it is reasonable to develop drugs with the polytropic effect on the pathogenesis of diabetes and herbal medicines possessing a polymodal protective action are under the inten- sive research in this context [12]. However, the data on the mechanisms of action of these drugs are insufficient.

Our efforts are directed towards the investigation of the pharmacological properties of Aegopodium podagraria L. (goutweed, GW). GW is a perennial plant of the Apiaceae family. A dry extract and the tincture standardized by hydroxycinnamic acids content have been obtained from the GW overground part. Proceeding from pharmacological effects of goutweed such as the hypoglycemic effect in intact rats (inherent for the tincture [3]), the beneficial effect on the uric acid metabolism (typical for the extract and the tincture [6]), the hepatoprotective and nephroprotective activity (proven for the extract $[4,6]$ ) the research of efficiency of the medicines with GW has been carried out in alloxan-

O.V.Tovchiga - Candidate of Pharmacy, teaching assistant of the Department of Pharmacology, National University of Pharmacy (Kharkiv)

V.O.Synytsia - head of the Regional Pathoanatomical Bureau, chief pathologist of the Department of Health in Chernihiv Regional State Administration

induced diabetic mice. Under these conditions the extract and the tincture with GW reduced hyperglycemia and normalized uricemia, the extract also revealed the hypoazotemic action, exhibited a clear tendency to proteinuria reduction and survival increase [5, 7]. Therefore, there is the necessity to conduct morphological verification of the protective effect of GW medicines.

The aim of this study is to determine the effect of medicines with goutweed on the histological structure of the kidneys and liver in alloxan-induced diabetic mice.

\section{Materials and Methods}

Adult randombred male mice (with the body weight of 17-20 g) obtained from the Central Research Laboratory of the National University of Pharmacy were used for this study in accordance with "Directive 2010/63/EU of the European Parliament and of the Council of 22 September 2010 on protection of animals used for scientific purposes." 
The diabetes model was induced by single subcutaneous introduction of alloxan in the dose of $200 \mathrm{mg} / \mathrm{kg}$ [1]. On the 3-rd day the mice with the blood glucose level more than $10 \mathrm{mmol} / \mathrm{l}$ were chosen and randomly divided into 6 groups as follows: untreated mice (diabetes control, $D C, n=9$ ), mice treated with the GW tincture in the doses of 1 and $5 \mathrm{ml} / \mathrm{kg}$ ( $\mathrm{n}=8$ and $\mathrm{n}=10$, respectively), mice treated with the GW extract in the dose of $1 \mathrm{~g} / \mathrm{kg}(\mathrm{n}=7$, the doses being effective in the previous experiments were used $[3,6])$, mice given the reference drug - officinal hypoglycemic herbal tea "Arphasetin" in the dose of $18 \mathrm{ml} / \mathrm{kg}$ $(n=7,[2])$.

The groups of diabetic mice did not differ in their glycemic level. The GW tincture (with alcohol removed before introduction), the GW extract (water solution) and "Arphasetin" tea infusion were introduced intragastrically once a day. The mice of the DC group, as well as the mice used as an intact control (IC, $n=7$ ) received the appropriate amount of distilled water. On the 3-rd week after the introduction of the last dose the animals were sacrificed under the lethal dose of barbiturate-induced anesthesia. The kidneys and liver were harvested, fixed in 10\% solution of neutral formalin and embedded in paraffin. Microtome cuts were stained with hematoxylin and eosin. For the analysis a "Granum R60-Lux" microscope (objective $\times 10, \times 40$, ocular EW10X/22) and a "Granum DC400" digital video camera with the appropriate software were used.

\section{Results and Discussion}

There were no renal histological alterations in the animals of the IC group with glomeruli and tubuli preserved. The normal nephrothelial structure is shown in Fig. 1. A typical histological structure of the liver was also evident in these mice (Fig. 2). During three weeks passed since alloxan introduction the kidneys and liver of

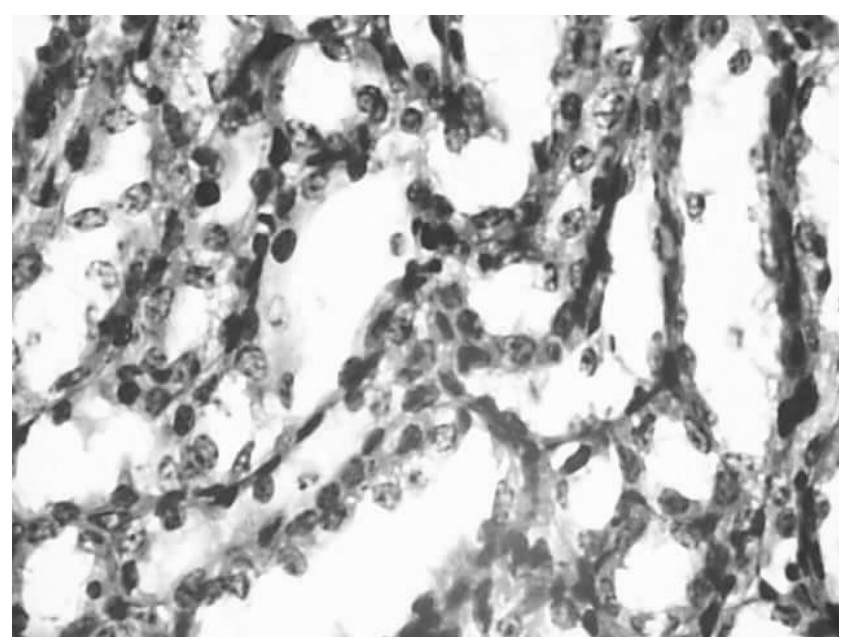

Fig. 1. A photomicrograph of the intact mouse kidney. The histological structure of the kidney is preserved with the normal nephrothelial structure. Hematoxylin and eosin staining. $\times 400$

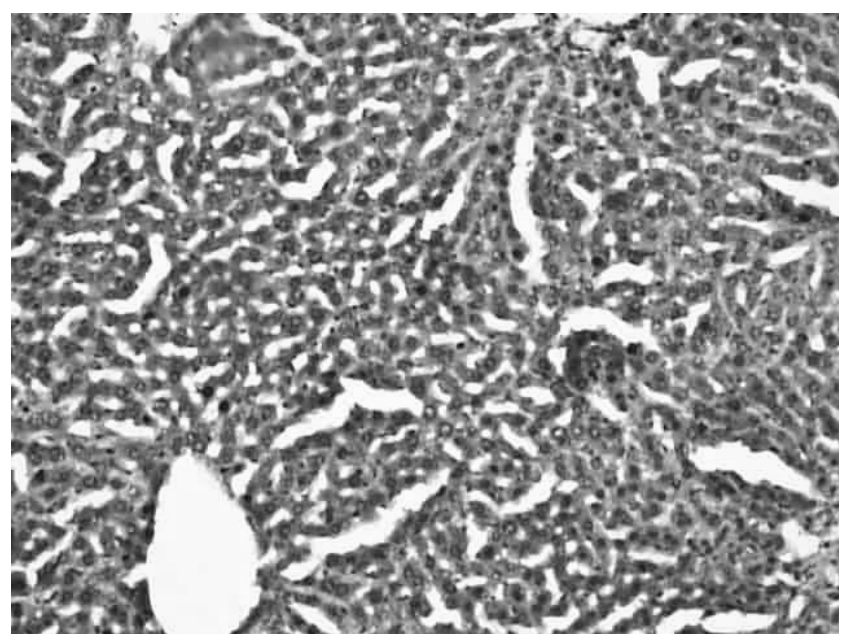

Fig. 2. A photomicrograph of the intact mouse liver. The histological structure of the liver is preserved. Hematoxylin and eosin staining. $\times 100$

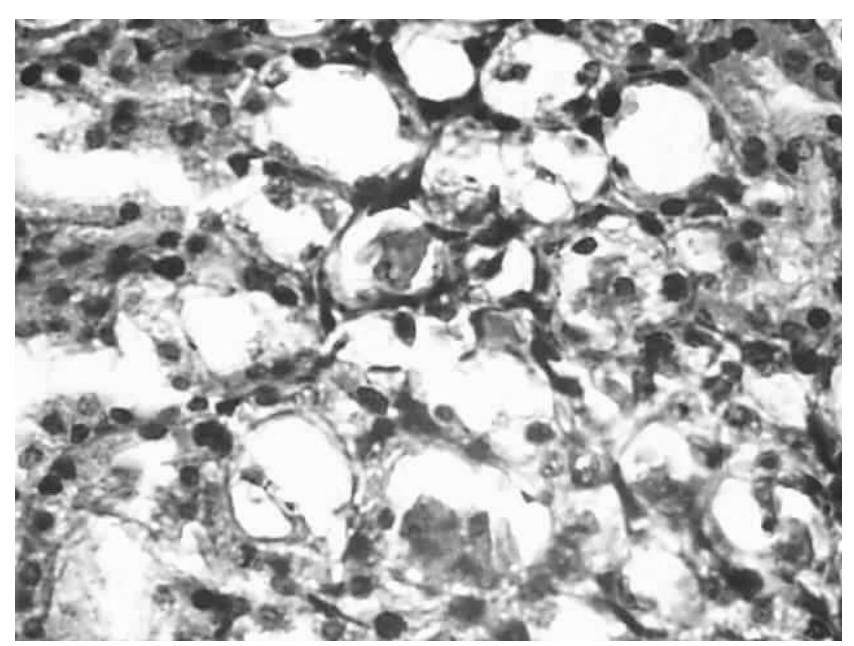

Fig. 3. A photomicrograph of the alloxan-induced diabetic mouse kidney (diabetes control), the third week. Necrobiosis of the tubular epithelium, protein infiltration of tubuli. Hematoxylin and eosin staining. $\times 400$ 


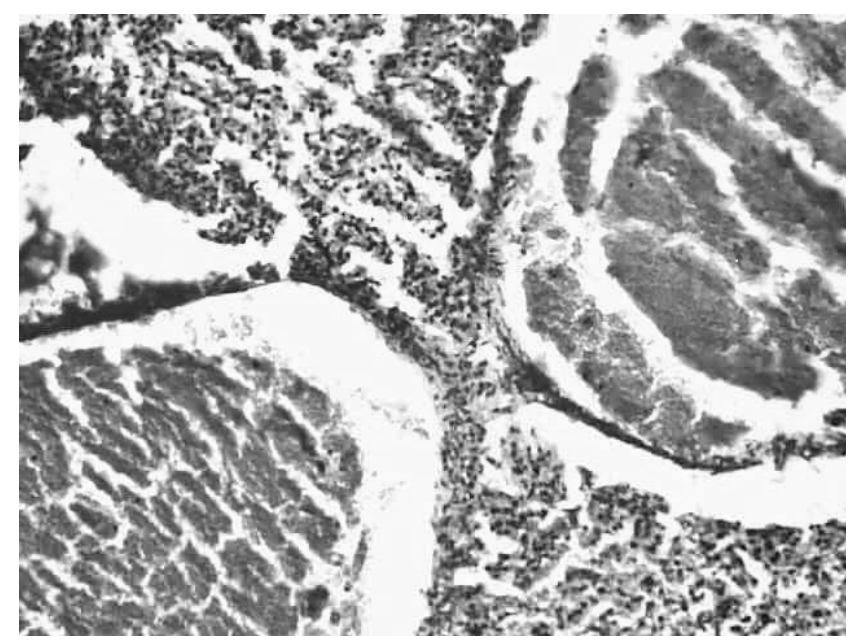

Fig. 4. A photomicrograph of the alloxan-induced diabetic mouse liver (diabetes control), the third week. A pronounced vascular plethora with the presence of erythrocytes. Hematoxylin and eosin staining. $\times 400$

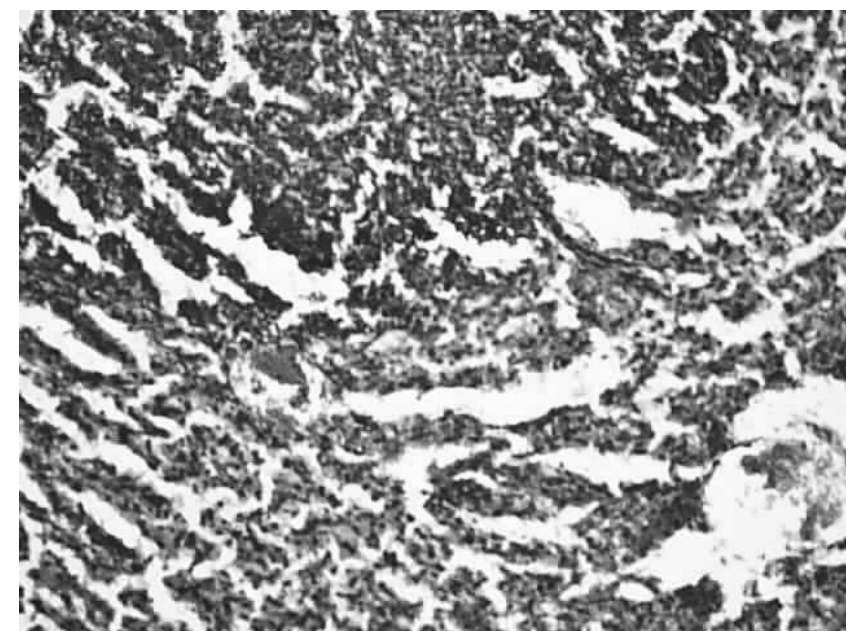

Fig. 5. A photomicrograph of the alloxan-induced diabetic mouse liver (diabetes control), the third week. Granular dystrophy of hepatocytes. Lympholeucocytal infiltration foci with necrobiosis and necrosis of hepatocytes. Hematoxylin and eosin staining. $\times 100$

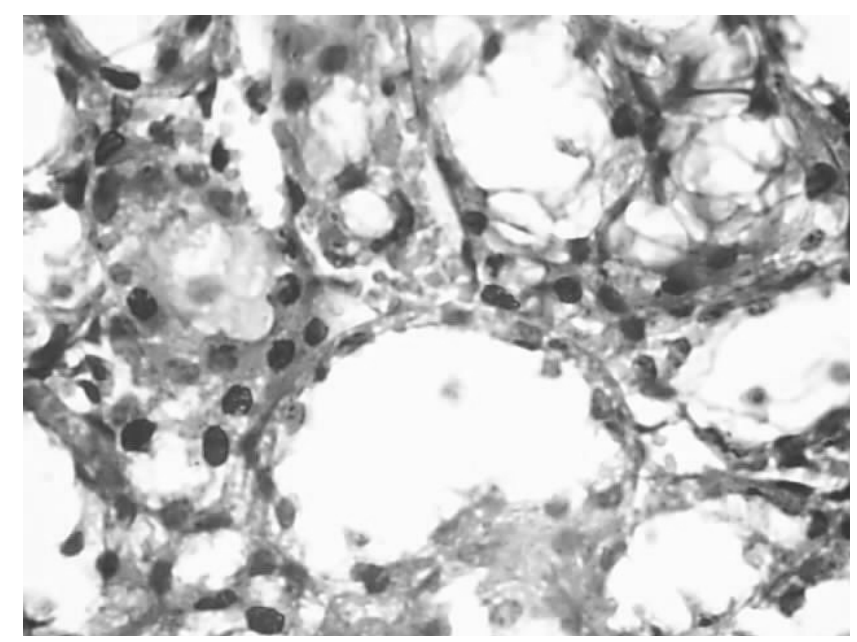

Fig. 6. A photomicrograph of the kidney of the alloxan-induced diabetic mouse (the third week) receiving the goutweed extract in the dose of $1 \mathrm{~g} / \mathrm{kg}$. The structure of tubuli is partially preserved, granular dystrophy and foci of necrobiosis of the tubular epithelium. Hematoxylin and eosin staining. $\times 400$ mice in the DC group underwent pathological changes. Thus, the vascular plethora was found in the kidneys, as well as granular degeneration of the tubular epithelium with necrobiosis of the epithelium in some tubuli and protein infiltration of tubuli (Fig. 3). Although the renal excretory function in this term is not significantly impaired, the tendency towards prognostically unfavourable hyperfiltration and increased proteinuria (that was severe in individual mice) indicates the possibility of the functional reserve exhaustion [7]. It is also consistent with the lack of significant morphological changes of glomeruli and with the tubular infiltration. A pronounced vascular plethora was detected in the liver (Fig. 4). Hepatocytes underwent dystrophic changes (granular dystrophy), in some samples the lympholeucocytal infiltration foci with necrobiosis and necrosis of hepatocytes were present (Fig. 5). These results correspond to the data in literature concerning the presence of pathological changes in the kidneys and liver already on the 9-th day after alloxan introduction [11] and development of lymphocytic infiltration and necrosis foci in the liver in 4 weeks of alloxan-induced diabetes progress [9].

The least pronounced changes of the kidneys and liver histological structure were observed in animals treated with the GW extract and "Arphasetin" tea infusion. In the kidneys of mice of both of these groups the structure of tubuli was predominantly preserved. The granular dystrophy of the nephrotelium, as well as the foci of necrobiosis were registered only in certain samples (Fig. 6, 8). The lack of protein infiltration of tubuli is consistent with the tendency to proteinuria reduction on the background of the GW extract [7]. Thus, the nephroprotective effect of this medicine proven [6] is evident under the conditions of alloxan-in- 
duced diabetes, with the extract administration for treatment, but not for prophylaxis. The nephroprotective effect is favourably associated with the hypoazotemic activity probably associated with extrarenal mechanisms [7].

In the liver sections of mice receiving the GW extract the vascular plethora and granular dystrophy of hepatocytes were detected. Some cells were in the state of hypertrophy (Fig. 7), which may be characterized as a load-induced hypertrophy. On the background of "Arphasetin" the changes in hepatic histological structure were also less pronounced compared to the DC group: the vascular plethora and granular dystrophy of hepatocytes were found (Fig. 4), as well as isolated foci of hepatocytes necrobiosis in some histological samples.

Therefore, both the GW extract and "Arphasetin" normalize the liver and kidney histological structure. However, with its integral protective effect the GW extract has advantages over the reference drug because the latter, in contrast to the GW extract, does not reduce blood glucose and the creatinine level $[5,7]$. It is likely that a combination of hypoglycemic, nephroand hepatoprotective effects results in survival increase, which is the highest on the background of the extract [5].

The GW tincture in the dose of $1 \mathrm{ml} / \mathrm{kg}$ significantly decreased glycemia and glucosuria, contributed to proteinuria reduction, though did not provide decrease in lethality of diabetic mice [5]. The research of the histological structure also indicated the lack of the protective activity: there were significant changes in the renal tubuli with foci of necrobiosis and necrosis of the tubular epithelium, expressed granular dystrophy of the nephrotelium and protein infiltration of tubuli, while the glomerular structure was preserved with only vascular plethora and a slight swelling being present

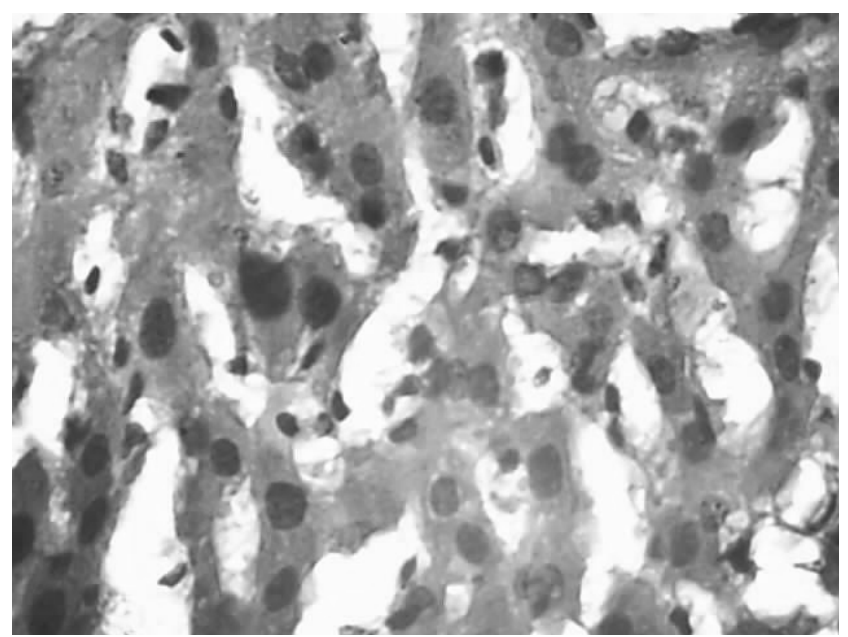

Fig. 7. A photomicrograph of the liver of the alloxan-induced diabetic mouse (the third week) receiving the goutweed extract in the dose of $1 \mathrm{~g} / \mathrm{kg}$. Granular dystrophy of hepatocytes, some of them in the state of hypertrophy. Hematoxylin and eosin staining. $\times 400$

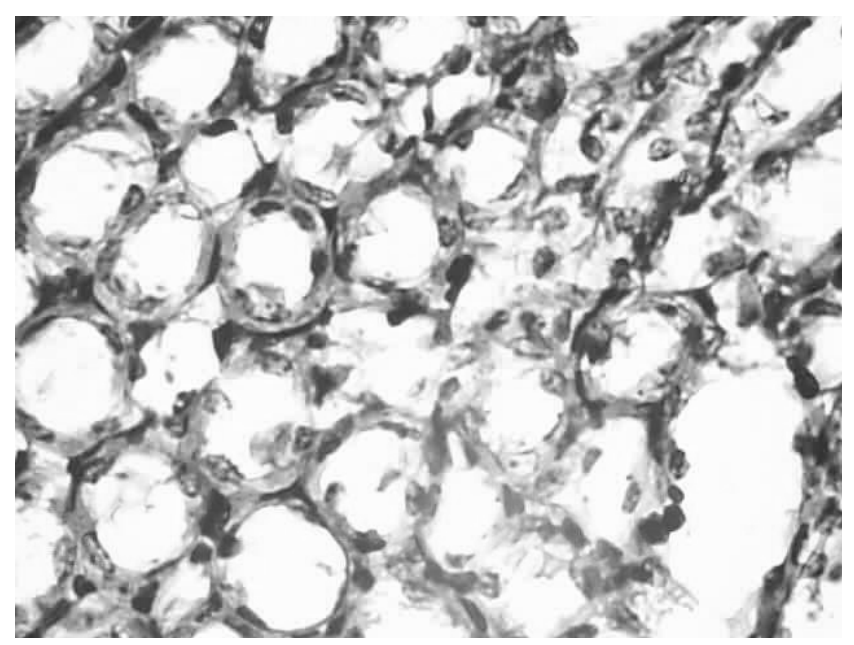

Fig. 8. A photomicrograph of the kidney of the alloxan-induced diabetic mouse (the third week) receiving "Arphasetin" tea infusion in the dose of $18 \mathrm{ml} / \mathrm{kg}$. The structure of tubuli is preserved, granular dystrophy of the tubular epithelium. Hematoxylin and eosin staining. $\times 400$

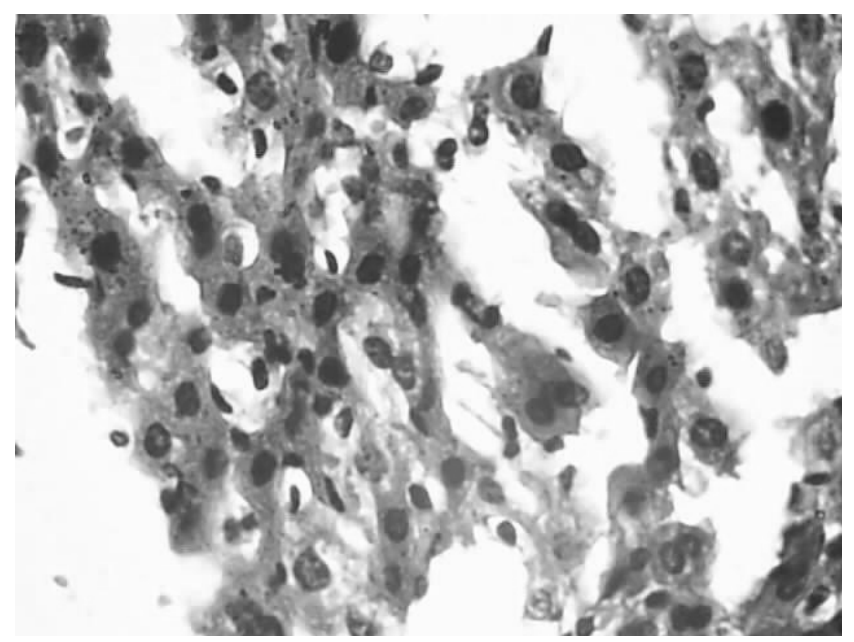

Fig. 9. A photomicrograph of the liver of the alloxan-induced diabetic mouse (the third week) receiving "Arphasetin" tea infusion in the dose of $18 \mathrm{ml} / \mathrm{kg}$. Vascular plethora and granular dystrophy of hepatocytes. Hematoxylin and eosin staining. $\times 400$ 


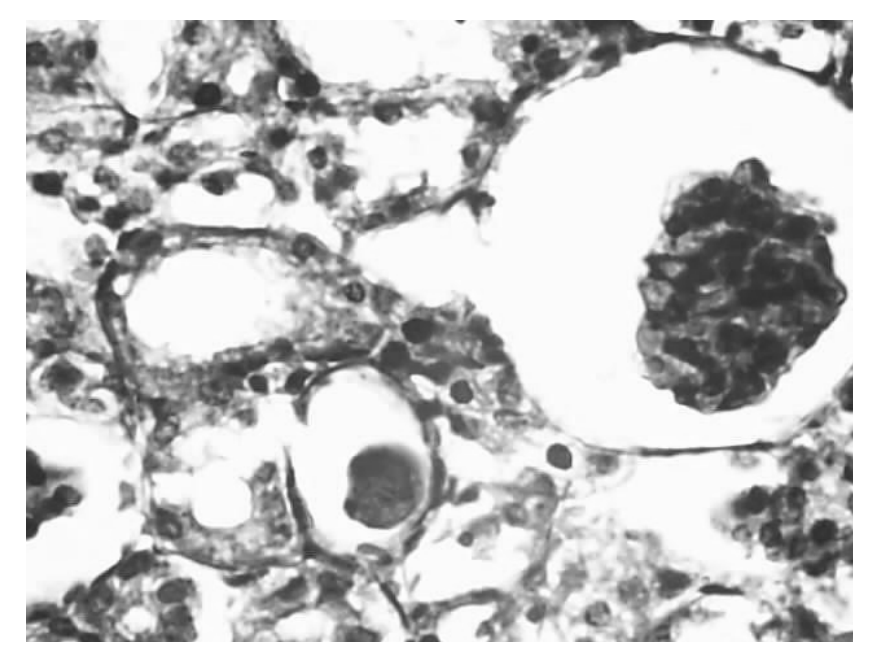

Fig. 10. A photomicrograph of the kidney of the alloxan-induced diabetic mouse (the third week) receiving the goutweed tincture in the dose of $1 \mathrm{ml} / \mathrm{kg}$. The glomerular structure is preserved, the vascular plethora and slight swelling. Necrosis and necrobiosis of the tubular epithelium, expressed granular dystrophy of the nephrotelium and protein infiltration of tubuli. Hematoxylin and eosin staining. $\times 400$

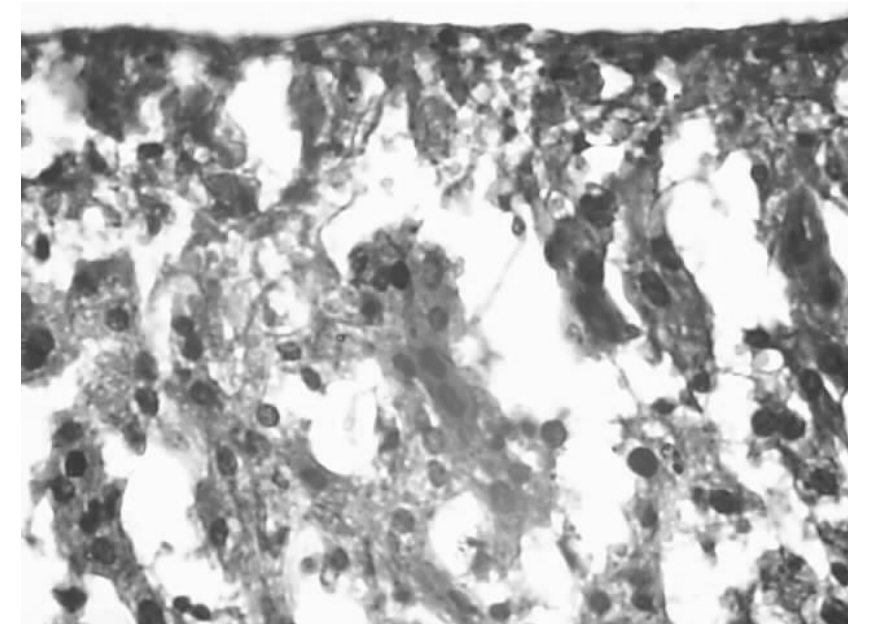

Fig. 11. A photomicrograph of the liver of the alloxan-induced diabetic mouse (the third week) receiving the goutweed tincture in the dose of $1 \mathrm{ml} / \mathrm{kg}$. Granular dystrophy and foci of necrosis of hepatocytes. Hematoxylin and eosin staining. $\times 400$

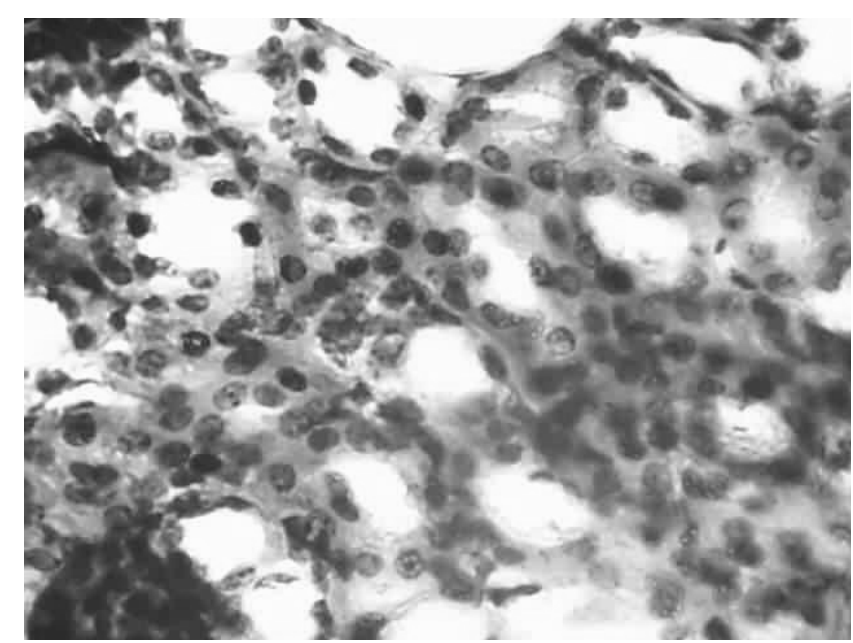

Fig. 12. A photomicrograph of the kidney of the alloxan-induced diabetic mouse (the third week) receiving the goutweed tincture in the dose of $5 \mathrm{ml} / \mathrm{kg}$. The structure of tubuli is partially preserved, granular dystrophy of the nephrothelium. Hematoxylin and eosin staining. $\times 400$
(Fig. 10). In the liver there was hepatocytes granular dystrophy and foci of necrosis of hepatocytes (Fig. 11). The increase in the GW tincture dose up to $5 \mathrm{ml} / \mathrm{kg}$ did not provide the increase in the protective effect according to the criteria of glycemia, the blood creatinine level and the glomerular filtration rate. The survival rate in this group was the lowest and had statistically significant differences from the value of the group treated with the GW extract. However, on the background of the tincture in the dose of $5 \mathrm{ml} / \mathrm{kg}$ necrosis and necrobiosis in the kidneys were not registered, while the vascular plethora and granular dystrophy of the tubular epithelium were detected (Fig. 12), as well as protein infiltration in some tubuli. Under the influence of the GW tincture in the dose of $5 \mathrm{ml} / \mathrm{kg}$ necrobiosis and necrosis of hepatocytes were not also found, there was only granular dystrophy and the irregular vascular plethora in the liver (Fig. 13).

Thus, in alloxan-induced diabetes mice no strict correspodence between biochemical, functional and morphological changes on the background of the GW tincture and "Arphasetin" tea infusion is observed. This may indicate an insufficient protective activity of these drugs on the integral level of the whole organism, despite some such positive effects registered as normalization of the histological structure of the kidney and liver by the GW tincture in the dose of $5 \mathrm{ml} / \mathrm{kg}$ and «Arphasetin», as well as favourable metabolic properties of the tincture in the dose of $1 \mathrm{ml} / \mathrm{kg}$. At the same time the GW extract in the dose of $1 \mathrm{~g} / \mathrm{kg}$ is characterized by the integral protective action: along with the normalization of glucose metabolism, increase in the survival rate, reduction in the blood creatinine level and tendency towards proteinuria decrease, it restores the normal histological structure of the kidneys and liver. Since the direct nephrotoxic and hepatotoxic effects 


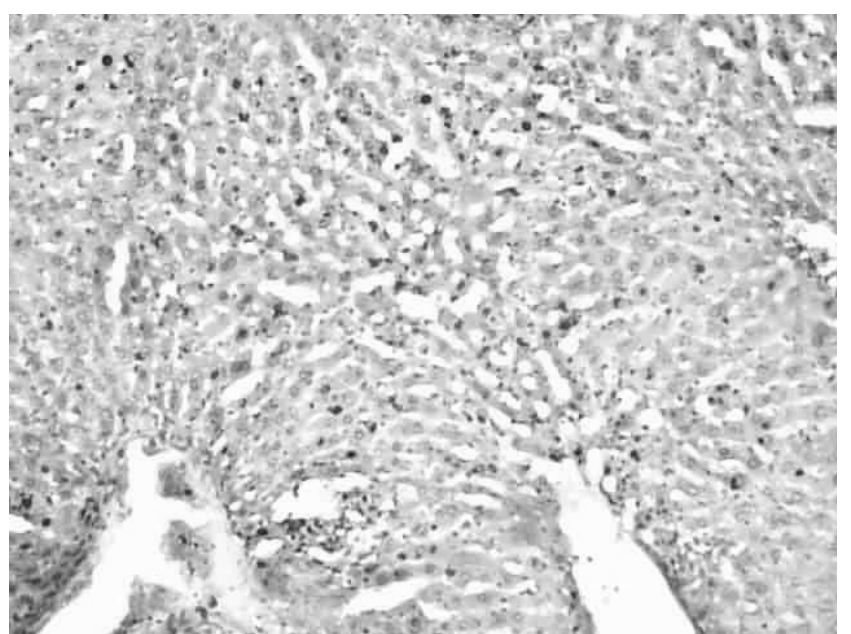

Fig. 13. A photomicrograph of the liver of the alloxan-induced diabetic mouse (the third week) receiving the goutweed tincture in the dose of $5 \mathrm{ml} / \mathrm{kg}$. Irregular vascular plethora alternating with decreased blood flow areas, granular dystrophy of hepatocytes. Hematoxylin and eosin staining. $\times 100$

of alloxan are due to the oxidative stress induction $[9,11]$, the results of the current study substan- tiate broadening of the spectrum of the cytoprotective action of the GW extract.
CONCLUSIONS

1. In three weeks after the pathological process induction in the nontreated mice dystrophic changes with the partial transition to necrobiosis and necrosis in the kidneys and liver, protein casts within the renal tubuli and lympholeucocytal infiltration in the liver were found.

2. A dry extract of goutweed $(1 \mathrm{~g} / \mathrm{kg})$, "Arphasetin" tea infusion $(18 \mathrm{ml} / \mathrm{kg})$, the goutweed tincture $(5 \mathrm{ml} / \mathrm{kg}$, but not $1 \mathrm{ml} / \mathrm{kg}) \mathrm{im}$ prove the histological structure of the kidneys and liver in alloxan-induced diabetic mice and, prevent necrosis development and protein infiltration of the renal tubuli.

3. On the basis of the experimental data the goutweed extract in the dose of $1 \mathrm{~g} / \mathrm{kg}$ is considered to be the most promising medicine for further research.

\section{REFERENCES}

1. Барнаулов О.Д., Поспелова М.Л. // Психофармакол. и биол. наркол. - 2005. - Т. 5, №4. - С. 1113-1120.

2. Кошова О.Ю., Яковлєва Л.В., Болоховець Г.С. та ін. // Клінічна фармація. - 2009. - Т. 13, №1. C. 64-67.

3. Пат. на кор. модель 69047 Україна МПК А 61 K 36/23 (2006.01), А 61 K 135/00 (2006.01), A 61 Р 3/10 (2006.01) / О.В.Товчига, С.Ю.Штриголь, С.І.Степанова. - № и 2011 09248. Заявл.: 25.07.11. Опубл.: 25.04.12. - 2012. - Бюл. №8. - 3 с.

4. Пат. на кор. модель 63764 Україна, МПК А 61 К 36/23 (2006.01), А 61 К 127/00 (2006.01) / О.О.Койро, С.Ю.Штриголь. - № и 201101332. Заявл.: 07.02.2011. Опубл.: 25.10.2011. - 2001. - Бюл. №20. $-3 \mathrm{c}$.

5. Товчига О.В. // Фармакол. та лік. токсикол. - 2012. - №5. - С. 73-78.

6. Товчига О.В. Дослідження сечогінної, нефропротекторної, гіпоурикемічної дії яглиці звичайної (Aegopodium podagraria L.) як основа для створення лікарських засобів : Автореф. дис. ... канд. фармац. наук: 14.03.05. - Х., 2009. - 21 с.

7. Товчига О.В., Штрыголь С.Ю. // Матер. Междунар. научн. конф. «Физиология и патология почек и водно-солевого обмена», посв. 100-летию со дня рождения проф. Н.Н.Прониной (19-20 дек. 2012 г.). - Владикавказ: ИПК «Литерра», 2012. - С. 197-202.

8. Dronavalli S., Duka I., Bakris G.L. // Nat. Clin. Pract. Endocrinol. Metab. - 2008. - Vol. 4, №8. - P. 444-452.

9. Farokhi F., Farkhad N.K., Togmechi A. et al. // Avicenna J. Phytomed. - 2012. - Vol. 2, №2. - P. 63-71.

10. Gaiani S., Avogaro A., Bombonato G. // J. Ultrasound. - 2009. - Vol. 12. - P. 1-5.

11. Oršolić N., Sirovina D., Končić M.Z. et al. // BMC Complem. Altern. Med. - 2012. - Vol. 12. - P. 117-132.

12. Prabhakar P.K., Doble M. // Curr. Diabetes Rev. - 2008. - Vol. 4, №4. - P. 291-308.

13. Shaw J.E., Sicree R.A., Zimmet P.Z. // Diabetes Res. Clin. Pract. - 2010. - Vol. 87, №1. - P. 4-14. 


\title{
СТРУКТУРНІ ЗМІНИ НИРОК ТА ПЕЧІНКИ МИШЕЙ З АЛОКСАНОВИМ ЦУКРОВИМ ДІАБЕТОМ ПРИ ВВЕДЕННІ ПРЕПАРАТІВ ЯГЛИЦІ ЗВИЧАЙНОÏ (AEGOPODIUM PODAGRARIA L.)
}

\section{О.В.Товчига, В.О.Синиця*, С.Ю.Штриголь, Н.В.Бездітко}

Національний фармацевтичний університет, Обласне патологоанатомічне бюро Чернігівської обл.*

Ключові слова: миші; алоксановий цукровий діабет; нирки; печінка; яглиця звичайна

\begin{abstract}
Досліджено вплив екстракту яглиці звичайної (1 г/кг), настойки яглиці звичайної (1 та 5 мл/кг) та настою збору «Арфазетин» $(18 \mathrm{Mл/кг)} \mathrm{на} \mathrm{гістоструктуру} \mathrm{нирок} \mathrm{та} \mathrm{печінки} \mathrm{мишей} \mathrm{з} \mathrm{алоксановим} \mathrm{діабетом.} \mathrm{На} \mathrm{третьо-}$ му тижні розвитку патології в нирках та печінці нелікованих тварин виявлені дистрофічні зміни з частковим переходом у некробіоз та некроз, у нирках - інфільтрацію канальців білком, у печінці - лімфолейкоцитарну інфільтрацію. Екстракт яглиці звичайної (1 г/к2) та настій збору «Арфазетин» (18 мл/кг) нормалізують структуру ниркових канальців (наявна зерниста дистрофія нефротелію, в окремих гістопрепаратах - вогнища некробіозу), протидіють патологічним змінам гепатоцитів (на тлі екстракту виявляли повнокровність судин, зернисту дистрофію гепатоцитів, гіпертрофію окремих клітин, на тлі «Арфазетину» до того ж реєстрували поодинокі вогнища некробіозу). У нирках та печінці тварин, які одержували настойку яглиці звичайної в дозі 5 мл/кг, не виявляли некрозу та некробіозу, була наявною повнокровність судин, у нирках - зерниста дистробія нефротелію з білковою інфільтрацією деяких канальців, у печінці - зерниста дистрофія гепатоцитів. Настойка яглиці звичайної в дозі $1 \mathrm{Mл/кг} \mathrm{не} \mathrm{чинила} \mathrm{захисного} \mathrm{впливу} \mathrm{на} \mathrm{гістоструктуру} \mathrm{нирок} \mathrm{та} \mathrm{печінки.} \mathrm{Таким} \mathrm{чином,}$ екстракт яглиці звичайної (1 г/к2), настойка яглиці звичайної (5, але не 1 мл/кг) та настій збору «Арфазетин» $(18 \mathrm{M} / \kappa 2)$ покращують гістоструктуру нирок та печінки мишей із алоксановим діабетом, протидіють розвитку некрозу, а також білковій інфільтрації ниркових канальців. Найбільш перспективним препаратом для подальших досліджень є екстракт яглиці звичайної в дозі 1 г/кг.
\end{abstract}

\section{СТРУКТУРНЫЕ ИЗМЕНЕНИЯ ПОЧЕК И ПЕЧЕНИ МЫШЕЙ С АЛЛОКСАНОВЫМ САХАРНЫМ ДИАБЕТОМ НА ФОНЕ ПРЕПАРАТОВ СНЫТИ ОБЫКНОВЕННОЙ (AEGOPODIUM PODAGRARIA L.)}

\section{О.В.Товчига, В.А.Синица*, С.Ю.Штрыголь, Н.В.Бездетко}

\section{Национальный фармацевтический университет, Областное патологоанатомическое бюро} Черниговской обл.*

Ключевые слова: мыши; аллоксановый сахарный диабет; почки; печень; сныть обыкновенная

\begin{abstract}
Исследовано влияние экстракта сныти обыкновенной (1 г/кг), настойки сныти обыкновенной (1 и 5 мл/кг) и настоя сбора «Арфазетин» (18 мл/кг) на гистоструктуру почек и печени мышей с аллоксановым диабетом. Через три недели после воспроизведения патологии в почках и печени нелеченных животных выявлены дистрофические изменения с частичным переходом в некроз и некробиоз, в почках - инфильтрация канальцев белком, в печени - лимфолейкоцитарная инфильтрация. Экстракт сныти обыкновенной (1 г/кг) и настой сбора «Арфазетин» нормализуют структуру почечных канальщев (присутствует зернистая дистрофия нефротелия, в отдельных гистопрепаратах - очаги некробиоза), противодействуют патологическим изменениям гепатоцитов (на фоне экстракта выявляли полнокровие сосудов, зернистую дистрофию гепатоцитов и гипертрофию отдельных клеток, на фоне «Арфазетина» к тому же регистрировали одиночные очаги некробиоза). В печени и почках животных, получавших настойку сныти обыкновенной в дозе 5 мл/кг, не выявляли некроза и некробиоза, присутствовало полнокровие сосудов, в почках - зернистая дистрофия нефротелия с белковой инфильтрацией некоторых канальщев, в печени - зернистая дистрофия гепатоцитов. Настойка сныти обыкновенной в дозе $1 \mathrm{мл/кг} \mathrm{не} \mathrm{оказывала} \mathrm{защитного} \mathrm{влияния} \mathrm{на} \mathrm{гистоструктуру} \mathrm{почек} \mathrm{и} \mathrm{печени.} \mathrm{Таким} \mathrm{образом,} \mathrm{экстракт} \mathrm{сныти}$ обыкновенной (1 г/к2), настойка сныти обыкновенной (5 мл/кг, но не 1 мл/кг) и настой сбора «Арфазетин» (18 мл/кг) нормализуют гистоструктуру почек и печени мышей с аллоксановым диабетом, противодействуют развитию некроза, а также белковой инфильтрации почечных канальцев. Наиболее перспективен для дальнейших исследований экстракт сныти обыкновенной в дозе 1 г/кг.
\end{abstract}

Address for correspondence:

53, Pushkinska str., Kharkiv, 61002, Ukraine.

Tel. (57) 706-30-69. E-mail: olga_234@mail.ru.

National University of Pharmacy 